\title{
A REVIEW OF SUSTAINABILITY ASSESSMENT TOOLS ON PRIORITIZING PHYSICAL SAFETY AND COMFORT TO EFFECTIVELY CONTROL ACCIDENTS IN STREETS OF COLOMBO
}

\author{
KUMARAGURUPARAN. A ${ }^{1}$, WIJESUNDARA. K.W.J.P2 \& WEERASINGHE. U.G.D ${ }^{3}$ \\ 1,2,3 Department of Architecture, University of Moratuwa, Katubedda, Sri Lanka \\ 1Kumaraguruparana.21@uom.lk, 2jwijesundara@uom.lk, 3gamiweer@uom.lk
}

\begin{abstract}
The definition of sustainability has evolved since it was defined by the Brundtland commission in 1987, and become comprehensive over time with defined social, environmental and economy based 'Sustainable Development Goals'. Today the necessity and feasibility of inclusion of safety and comfort as key components of sustainable development of urban streets has become vital considering the number of accidents and crimes taking place in urban contexts. High number of road accidents have been recorded in Colombo as noted from the report issued by the Sri Lanka Department of Census and Statistics. This is primarily due to lack of regulations or any ratification on enforcing physical safety and comfort aspects. Therefore considering the principles of sustainability, and sustainability rating being established an universal quality assessment tool, it is important to incorporate physical safety and comfort as an element of sustainability in designing urban streets. The analysis is done by defining sustainability through literature review, identifying the research gap on physical safety and comfort using VOSviewer software, and assessing the significance of safety and comfort in designing urban streets using available online data.
\end{abstract}

Keywords: Sustainability; physical safety; physical comfort; street accidents; Colombo.

\section{Introduction}

This study defines physical safety and comfort of a space as the physical ease and protection sensed by the user, when components of design that ensure the safety and comfort are established appropriate to location with ergonomic standards (Ahmed-Kristensen, S., \& Stavrakos, S-K., 2012). These elements should be appropriately combined with suitable design layout and signage to spontaneously direct people to abide to the regulations and thereby ensure safety and comfort. Though it is ideal to incorporate these guidelines with street design regulations, the pragmatic approach would be to include them as elements of 'sustainability', which is at present a well-established quality assessment criteria, and considered as trending design 'status'.

The economic, environmental, and social aspects, were considered the 'three pillars' of sustainable development concept and later in 1995, political-institutional was added as a fourth dimension (Burford G et al., 2013). None of those 'pillars' address the improvement of physical safety and comfort aspects of street or any public realm, other than urban renewal concepts that focus on improving physical conditions of buildings as stated by Yıldı et al (2020). It is observed that the definition of sustainability had evolved over time with incorporation of various characteristics from diverse fields of development. Yet, neither the latest definitions by the United Nations nor their development goals specify the requisite of physical safety and comfort. Further, the code on physical comfort proposed by the National Institute of Building Sciences (2018) of the US, defines only the elements of buildings to ensure human comfort. Global street design guide by Global Design Cities Initiative (2016), that address physical safety and comfort is a reference document for street design and therefore is not necessarily followed. There is no well-defined universal 
code of practice or regulation that ensures physical safety and comfort at public realm, especially at streets where human are more vulnerable to unforeseen mishaps such as accidents.

As per the Sri Lanka Department of Census and Statistics (2019), a higher number of road accidents are recorded from Colombo than other parts of the country. In the year of 2019 the number of road accidents reported to police in the country is 30,433 ; in Colombo it is 3326 which is $10.92 \%$ of total accidents in the country, and persons killed in Colombo due to road accidents is 2829 (Sri Lanka Department of Census and Statistics, 2019). The sustainable goal is to halve this number of deaths by 2020 (World Health Organization, 2017). From 2013 to 2019, the number of accidents that are reported have been reduced by $19.66 \%$, and yet the number of persons killed due to road accidents had increased from 2013 to 2018 by $25.05 \%$ and again from 2018 to 2019 reduced by only 9.91\% (Figure 5) (Department of Census and Statistics, 2018).

The United Nations Global Status Report (WHO, 2018) depicts the universality of the problem. Road traffic crashes are globally identified as the ninth top cause for death at all ages (WHO, 2017). The World Health Organization Facts Sheet on Road Traffic Injuries (2020) states that globally approximately 1.35 million people die, and about 20-50 million people get injured annually due to road traffic crashes, and more than $50 \%$ of them are vulnerable users such as pedestrian, cyclists and motorcyclists. The severity of road crashes leads to social as well as economic problems. It costs around 1-3\% of the National Gross Product of any country (WHO, 2017). The report suggests a safe road that accommodates human error to subside the accidents, though the main causes of accidents are: over speeding, driving under psychoactive substance, ignorance of wearing helmets and seat belts, etc. (WHO, 2020). The roads should be designed in such a way to spontaneously make the users adopt to the road safety aspects (WHO, 2017), and it is vital to include such design guides ensuring physical safety and comfort, using an effective tool.

Thus the research aim is to identify the significance of physical safety and comfort as an element of sustainability in designing and assessing urban realm to reduce the rate of road accidents, which is identified as a contemporary global issue.

\section{Methodology}

The severity of road accidents is identified using global as well as Sri Lankan reports on state of the issue and relevant actions taken. The literature review is carried out to: summarize the globally accepted definitions of sustainability, and identify the significance and inclusion of the physical safety and comfort aspects in sustainability assessment tools vis à vis designing urban streets and thereby reducing street accidents. Identifying knowledge gap in research is done using VOSviewer software and SCOPUS database. Significance of physical safety and comfort of streets in reducing accidents, and it's requisite in the sustainability assessment tools are analysed with case study of Colombo, and supportive literature source.

\section{Scope and limitations}

Literature review on sustainability concept and sustainability assessment tools are limited to sources available online. Knowledge gap identification is limited to SCOPUS database as it is the only accessible licensed research citation database with a vast collection of highly standardized research articles supported by the VOSviewer software. The assessment of state of road accidents is limited to United Nations global report and Sri Lanka police records published by the Sri Lanka Department of Census and Statistics instead of onsite data collection, due to the existing COVID-19 travel restrictions and safety precautions.

\section{Literature Analysis using VOSviewer software}

Literature analysis is done using VOSviewer software. Journals selected for analysis are limited to publications in English, extracted from the SCOPUS research journal database. Journals that discuss the sustainable development based upon physical safety and comfort are obtained through application of Boolean expression: '( ("physical safety" OR "physical comfort") AND sustainability )'. Accordingly 16 journals are summarized. Analysis through VOSviewer software depicts (figure.01) the ignorance of physical safety and comfort in considering a sustainable development in the public realm. Figure 02 depicts the keywords that are more relevant to physical safety and comfort. It could also be observed that only most recent research topics are more relevant towards urban sustainability, and analyses the rating tools, yet do not specify or discuss physical safety and comfort of public realm (figure 01). Physical comfort is 
widely assessed based on the thermal and environmental factors rather than on ergonomics or anthropometrics. Research articles on sustaining communities and other social aspects have been discussed as a major component of sustainable urban design, and a knowledge gap exists regarding the inclusion of physical safety and comfort. Most research on sustainability at urban development are done by researchers from the United States, China, Turkey, Italy, United Kingdom, Bangladesh, Australia etc. which would not be suitable to adopt to the context of Sri Lanka.

It is vital that a research on significance of physical safety and comfort and inclusion of this element in assessing the sustainability of public realm to reduce street accidents be carried out on the Sri Lankan context where traffic fatality number still remains high as per the Department of Census and Statistics. (2019). This knowledge gap is proven through VOSviewer software bibliometric analysis on keywords (figures 1, and 2).

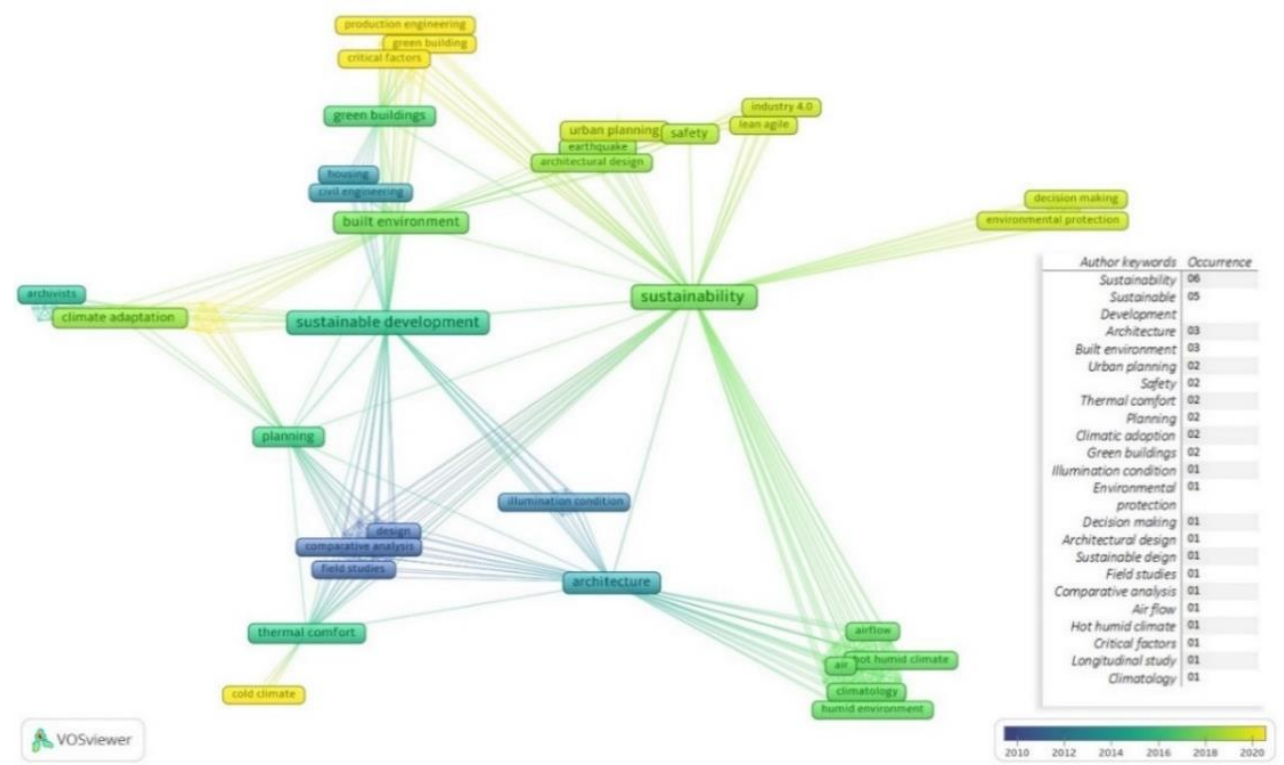

Figure1, Network visualization of author keywords of all research articles in the SCOPUS (VOSviewer, 2021)

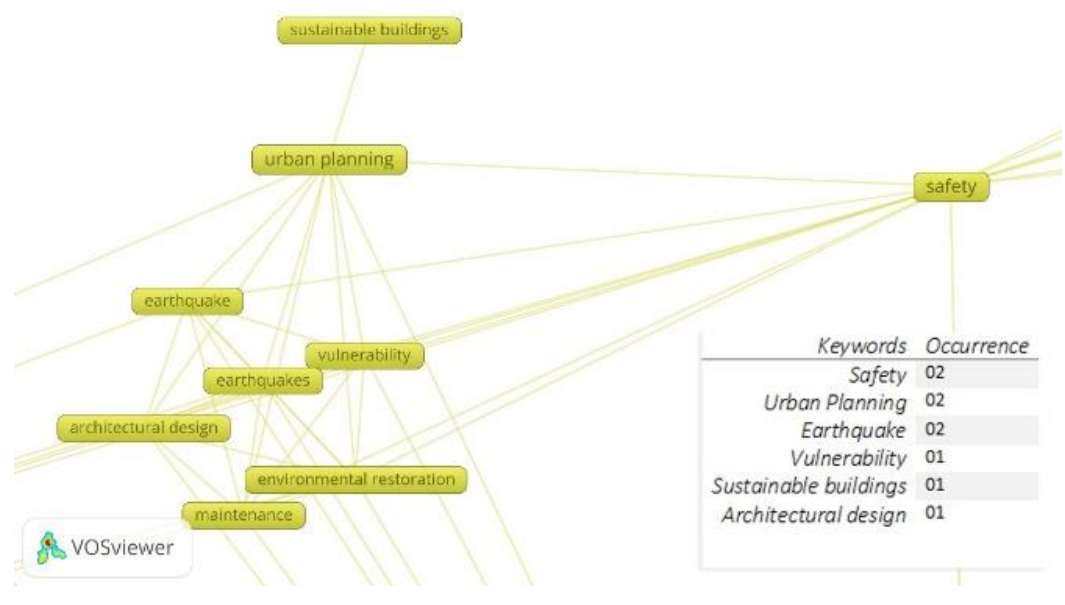

Figure 2, Most relevant keywords to physical comfort and safety of all research articles in the SCOPUS (VOSviewer, 2021)

\section{Significance of physical safety and comfort in reducing street accidents}

Streets which are the major connectors of places, occupy $80 \%$ of urban space and however fail to ensure user safety and comfort (National Association of City Transportation Officials [NACTO], 2017). Urbanization and urban population are frequently increasing (The World Bank, 2020b), and simultaneously the road accident death rates are also increasing (WHO, 2018). Sri Lanka records the worst 
road accident fatalities amidst the South Asian region (WHO, 2018), while the vehicle ownership also rapidly increases (The World Bank, 2020). The main causes for road accidents in Sri Lanka as identified by Perera, Clifford (2016) and The World Bank (2020) are: negligence of users, increased vehicular numbers while the road expansions are insufficient and poorly connected, inefficient legal system, and poor public transport system. Through years the legal system has been developed to ensure safety (The World Bank, 2020) and yet the number of fatalities are continuously rising (Department of Census and Statistics, 2019). Therefore as stated by the WHO (2018), regardless of the cause, it is important to design streets complying with standards to ensure physical safety and comfort of users to spontaneously direct the users in the right path, and to incorporate protective elements such as buffers. Despite the causes, it is the physical collisions that result in injuries and deaths (William W. Harper, 1952-1953), therefore roads should be designed appropriately to prevent physical collisions.

Elevating road safety in the streets of Colombo is vital to augment the well-being of people as well as the national economy (The World Bank, 2020). The Sri Lankan authorities responsible for management of road safety are inefficient due to the lack of authority, resources, and tools, and it is necessary to integrate a tool to asses, implement and maintain road safety to ensure physical safety and comfort, which is the prime solution to the research problem (The World Bank, 2020). Therefore, as discussed, sustainability tools are the globally accepted and well established models, through which implementation of physical safety and comfort could be ensured.

\section{Significance of physical safety and comfort in the international concept of sustainability}

Providing physically comfort elements such as shading devices through walkways could improve active transportation (Sun et al., 2020) beyond just providing safety. It leads to reduction of motor vehicular functions and thereby energy consumption, increases human health and safety, and contribute in achieving many other sustainability goals (World Health Organization, 2017). Therefore it is necessary to identify the significance of physical safety and comfort in the present concept of sustainability.

\subsection{ANALYSIS OF UN SUSTAINABILITY CONCEPTS AND SIGNIFICANCE OF PHYSICAL SAFETY AND COMFORT}

The United Nations (UN) is an internationally influential organization (Novosad, P., Werker, E., 2019) and sustainability is a universally trending concept. Therefore the decisions and plans of the UN on sustainability makes a remarkable global impact, thus it is important to analyse the inclusion and significance of physical safety and comfort in the UN concept on sustainability to efficiently decrease the road accident rates.

Traffic death rate was a concern raised by the UN in developing the 2030 Agenda for Sustainable Development from the Millennium Achievement Goals, in 2015 (United Nations Development Programme, 2015). This Agenda targets to halve the road traffic deaths and injuries by 2020 (WHO, 2017). Accordingly, 'The Safe System approach' proposed by the World Health Organization on controlling Road Traffic Injuries (WHO, 2017) states that roads should be designed to forgive human error. The Road Safety Technical Package of this approach proposes 06 effective strategies to reduce traffic crash impacts and contributes in achieving Sustainable Development Goal targets 3.6 which is to halve the number of victims of road accidents, and target 11.2 which is to provide safe and affordable access to sustainable transport systems for all, while prioritizing vulnerable groups (United Nations Development Programme, 2015). Strategies on 'Speed management' and 'Infrastructure Design and Improvement' would require the inclusion of physical safety and comfort factors though they have not been directly quoted.

\begin{tabular}{|l|l|l|l|l|}
\hline $\begin{array}{l}\text { Goal } \\
\text { No. }\end{array}$ & UN Sustainable Goals & $\begin{array}{l}\text { Important aspects } \\
\text { considered }\end{array}$ & \multicolumn{2}{l|}{ Targets } \\
\hline 03 & $\begin{array}{l}\text { Good health and well- } \\
\text { being }\end{array}$ & $\begin{array}{l}\text { Ensure good health and } \\
\text { well-being for all ages }\end{array}$ & 3.6 & $\begin{array}{l}\text { By 2020, halve the number of global deaths } \\
\text { and injuries from road traffic accidents }\end{array}$ \\
\hline 09 & $\begin{array}{l}\text { Industry, innovation } \\
\text { and infrastructure }\end{array}$ & $\begin{array}{l}\text { Establish strong } \\
\text { infrastructure, } \\
\text { promoting inclusive and } \\
\text { sustainable } \\
\text { industrialization and } \\
\text { foster innovation }\end{array}$ & 9.1 & $\begin{array}{l}\text { Develop quality, reliable, sustainable and } \\
\text { resilient infrastructure, including regional } \\
\text { and transborder infrastructure, to support } \\
\text { economic development and human well- } \\
\text { being, with a focus on affordable and } \\
\text { equitable access for all }\end{array}$ \\
\hline 11 & $\begin{array}{l}\text { Sustainable cities and } \\
\text { communities }\end{array}$ & $\begin{array}{l}\text { Promote sustainable } \\
\text { cities and inclusive and } \\
\text { safe human settlements }\end{array}$ & 11.2 & $\begin{array}{l}\text { By 2030, provide access to safe, affordable, } \\
\text { accessible and sustainable transport } \\
\text { systems for all, improving road safety, }\end{array}$ \\
\hline
\end{tabular}




\begin{tabular}{|l|l|l|l|}
\hline & & & $\begin{array}{l}\text { notably by expanding public transport, } \\
\text { with special attention to the needs of those } \\
\text { in vulnerable situations, women, children, } \\
\text { persons with disabilities and older persons }\end{array}$ \\
\hline
\end{tabular}

Table 1, Sustainable Development Goals on urban development and human safety and comfort (United Nations Development Programme, 2015)

Considering the Sustainability Development Goals (SDG) proposed by the UN, only SDG 3, 9 and 11 address the issues relevant to the research problem. As could be noted from Table 1, only Sustainable Development Goals (SDG) 3 and 11 directly emphasize human safety and health, while SDG 9 emphasizes a resilient and innovative infrastructure which indirectly ensures economic stability and human wellbeing. All three goals are influenced by multiple factors, and none directly highlight the inclusion of physical safety and comfort as an element of sustainable design of public realm.

'Save lives - A road safety technical package' (WHO, 2017) proposes a safe system approach based up on the Sweden's vision zero strategy (Kristianssen, A.-C., Andersson, R., Belin, M.-Å., \& Nilsen, P., 2018). This approach consists of various framework to a holistic assessment of road traffic injury risk factors and interventions (WHO, 2017). This approach emphasizes, 'Education and information', 'Innovation', 'Monitoring, management and coordination', 'Data analysis, research and evaluation', 'Road rules and enforcement', and 'Licensing and registration' as key elements and identifies six major components and interventions (figure 3) to achieve the sustainability goal (WHO, 2017, p. 9). The intention of the approach is to establish safe roads through appropriate design.

\begin{tabular}{|c|c|c|}
\hline Acronym & Component & Interventions \\
\hline \multirow{3}{*}{$\pi x$} & \multirow{3}{*}{$\begin{array}{l}\text { Speed } \\
\text { management }\end{array}$} & Establish and enforce speed limit laws nationwide, locally and in cities \\
\hline & & $\begin{array}{l}\text { Build or modify roads which calm traffic, e.g. roundabouts, road narrowing, } \\
\text { speed bumps, chicanes and rumble strips }\end{array}$ \\
\hline & & $\begin{array}{l}\text { Require car makers to install new technologies, such as intelligent speed } \\
\text { adaptation, to help drivers keep to speed limits }\end{array}$ \\
\hline \multirow{5}{*}{ 용 일 } & \multirow{5}{*}{$\begin{array}{l}\text { Leadership on } \\
\text { road safety }\end{array}$} & Create an agency to spearhead road safely \\
\hline & & Develop and fund a road safety strategy \\
\hline & & Evaluate the impact of road safety strategies \\
\hline & & Monitor road safety by strengthening data systems \\
\hline & & Raise awareness and public support through education and campaigns \\
\hline \multirow{8}{*}{$=\mid \prod_{r}^{m}$} & \multirow{8}{*}{$\begin{array}{l}\text { Infrastructure } \\
\text { design and } \\
\text { improvement }\end{array}$} & $\begin{array}{l}\text { Provide safe infrastructure for all road users including sidewalks, safe crossings, } \\
\text { refuges, overpasses and underpasses }\end{array}$ \\
\hline & & Put in place bicycle and motorcycle lanes \\
\hline & & $\begin{array}{l}\text { Make the sides of roads safer by using clear zones, collapsible structures or } \\
\text { barriers }\end{array}$ \\
\hline & & Design safer intersections \\
\hline & & Separate access roads from through-roads \\
\hline & & Prioritize people by putting in place vehicle-free zones \\
\hline & & Restrict traffic and speed in residential, commercial and school zones \\
\hline & & Provide better, safer routes for public transport \\
\hline \multirow[t]{2}{*}{$\Delta=0$} & \multirow[t]{2}{*}{$\begin{array}{l}\text { Vehicle safety } \\
\text { standards }\end{array}$} & $\begin{array}{l}\text { Establish and enforce motor vehicle safety standard regulations related to: } \\
\text { seat-belts; } \\
\text { seat-belt anchorages; } \quad \text { electronic stability control; } \\
\text { frontal impact; } \\
\text { side impact; }\end{array}$ \\
\hline & & $\begin{array}{l}\text { Establish and enforce regulations on motorcycle anti-lock braking and daytime } \\
\text { running lights }\end{array}$ \\
\hline 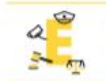 & $\begin{array}{l}\text { Enforcement of } \\
\text { traffic laws }\end{array}$ & $\begin{array}{l}\text { Establish and enforce laws at national, local and city levels on: } \\
\text { drinking and driving; } \quad \text { seat-belts; and } \\
\text { motorcycle helmets; } \\
\text { child restraints }\end{array}$ \\
\hline \multirow{3}{*}{ [3] } & \multirow{3}{*}{$\begin{array}{l}\text { Survival after } \\
\text { a crash }\end{array}$} & $\begin{array}{l}\text { Develop organized and integrated prehospital and facility-based emergency care } \\
\text { systems }\end{array}$ \\
\hline & & Train those who respond to crashes in basic emergency care \\
\hline & & Promote community first responder training \\
\hline
\end{tabular}

Figure 3, Save LIVES: six components and 22 interventions (World Health Organization, 2017)

Safety cannot be achieved through a single factor or a one way process, and needs a holistic approach of all the above mentioned key factors, and hence, it is important to confirm that the key factors address all relevant physical safety and comfort determinants. Enforcement of road rules is very important, yet how it should be achieved is what should be prioritized. As such, formulating and implementing road rules at design stages is vital in spontaneously controlling the accidents. Therefore physical safety and comfort should be included in the 'Road rules and enforcement' element. Rules and regulations are compulsory, yet in reality are easily disregarded and that is unidentified until the flaw occurs. Application of sustainability index tool at design stage could clearly depict a quantity identifying the impacts at design stages, preventing inefficient constructions (Yigitcanlar, T., \& Dur, F., 2010). Therefore it would be efficient 
to include the conformity of physical safety and comfort as an element of sustainability design index to achieve the sustainability goals effectively to ensure reduction of traffic crashes.

The infrastructure design and improvement of roads proposed by World Health Organization (2017) through 'Save lives - A road safety technical package' proposes solutions that ensure physical safety and comfort, such as: providing safe road infrastructure, making safe road sides and intersections, implementing cycle lanes, etc. It also emphasizes the need for assessing road safety strategy implementation efficiency; however does not address all the necessary components of roads in detail. Hence, ensuring physical safety and comfort as one of the key element of development with detailed identification of the components of roads could efficiently contribute to reduction of road crashes.

\subsection{ANALYSIS OF UNECE SUSTAINABILITY CONCEPTS AND INCLUSION OF PHYSICAL SAFETY AND COMFORT}

United Nations Economic Commission for Europe (UNECE) is a commission that offers regional framework to 56 European countries on elaboration and harmonization of standards and conventions. The UNECE Sustainable Transport Division sets its focus on road safety based upon the United Nations 2011 Global Plan for the Decade of Action for Road Safety (UNECE, 2015). UNECE (2015) states that any safety strategy should harmoniously address the heterogeneric users. The road system in Sweden where safety is prioritized in design and construction, rather convenience and speed is set as an example (UNECE, 2015). Yet ignorance of physical comfort of user could again lead to road accidents. For example, if the side walk surface finish is not smooth or well levelled, it could cause pedestrians to fall, which at adverse condition may lead to death. Therefore it is important to provide prominence to both physical safety and comfort to develop a sustainable design, which is not emphasized in the UNECE sustainability concept. The UNECE (2015) derived 11 goals from the five pillars of the UN Global Plan (Table 2) to formulate a strategy for the decade, to achieve road safety, and the main goal of reducing the road traffic injuries and deaths by $50 \%$. None of the goals emphasize the importance of inclusion of physical safety and comfort in designing streets.

Road safety is primarily determined by regulations and its efficient enforcement. With increased globalization and tourism, it is important that such regulations are set to universal standards in order for anyone from any part of the world to access the roads at any street in the world safely (UNECE, 2015). The UN conventions and agreements are formulated so as to ensure road safety, yet are not recognized or prioritized as other matters. However, the best acknowledged, and practiced universal tool is the 'sustainability' measure, which also does not emphasize the need for inclusion of physical safety and comfort as an assessment criteria.

\begin{tabular}{|c|c|}
\hline Five Pillars of UN Global Plan & 11 Goals of the UNECE Action Plan \\
\hline 1. Road safety management & $\begin{array}{l}\text { 1. Boost political will and support government } \\
\text { strategies }\end{array}$ \\
\hline 2. Safer road users & $\begin{array}{l}\text { 2. Protect vulnerable road users } \\
\text { 3. Turn road safety training, education and behaviour } \\
\text { into knowledge management } \\
\text { 4. Raise awareness, fundraise and advocate for road } \\
\text { safety }\end{array}$ \\
\hline 3. Safer roads and mobility & $\begin{array}{l}\text { 5. Make roads safer (including tunnels, rules, signs and } \\
\text { signals) } \\
\text { 6. Make technologies work for safer mobility }\end{array}$ \\
\hline 4. Safer vehicles & $\begin{array}{l}\text { 7. Make vehicles safer } \\
\text { 8. Improve cargo safety } \\
\text { 9. Improve the safety of transporting dangerous goods }\end{array}$ \\
\hline 5. Post-crash response & $\begin{array}{l}\text { 10. Mitigate the impact of road crashes } \\
\text { 11. Learn from road crashes }\end{array}$ \\
\hline
\end{tabular}

Table 2, Summary of Global Plan 'Pillars' and Action Plan Goals (UNECE, 2015)

In summary, the international concept on sustainability does not clearly prioritize the Significance of physical safety and comfort with regard to urban planning or street design.

\section{Significance of physical safety and comfort in the urban sustainability assessment tools}


Sustainability Assessment (SA) is a scientific evaluation for decision making (Serenella Sala, Biagio Ciuffo, Peter Nijkamp, 2015). A range of sustainability measurement tools are used globally. Among them, four most extensively used international urban sustainability assessment tools are considered in this analysis: Comprehensive Assessment System for Built Environment Efficiency (CASBEE), Green Building Index (GBI), Building Research Establishment Environmental Assessment Method (BREEAM) \& Civil Engineering Environmental Quality Assessment \& Award Scheme (CEEQUAL) by BRE, and Leadership in Energy and Environmental Design (LEED) for Cities and communities (Harsimran Kaur, Pushplata Garg, 2019) based on the consideration of urban context and popularity in usage.

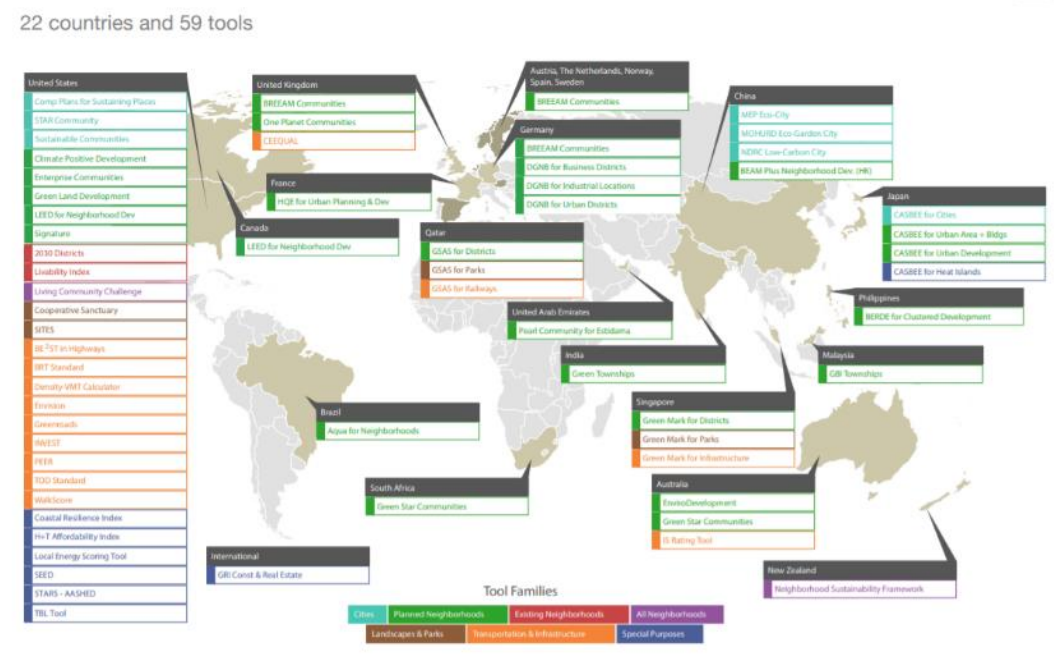

Figure 4, A Global Survey of Urban Sustainability Rating Tools (Criterion Planners - a Global Survey of Urban Sustainability Rating Tools

\subsection{COMPREHENSIVE ASSESSMENT SYSTEM FOR BUILT ENVIRONMENT EFFICIENCY (CASBEE)}

CASBEE is a tool developed by the Japan Sustainable Building Association with the support of Ministry of Land, Infrastructure, Transport and Tourism and announced in 2003 to evaluate the environmental performance rooted from Social, Environmental and Economic aspects (Japan Sustainable Building Association, 2014). "CASBEE-City" tool is used to evaluate the environmental performance of cities. No concern is provided vis à vis physical safety and comfort.

\subsection{GREEN BUILDING INDEX (GBI)}

GBI is an environmental rating system developed by the Malaysian Institute of Architects based on six core criteria: Climate, Energy and Water, Ecology and Environment, Community Planning and Design, Transportation and Connectivity, Building and Resources, and Business and Innovation (GSB, 2017). Designed to address the environmental, social and economic issues. In this tool as well, the physical safety and comfort aspect is ignored.

\subsection{BUILDING RESEARCH ESTABLISHMENT ENVIRONMENTAL ASSESSMENT METHOD (BREEAM)- THE CIVIL ENGINEERING ENVIRONMENTAL QUALITY ASSESSMENT \& AWARD SCHEME (CEEQUAL)}

BREEAM, first launched in 1990, is developed to assess the environmental, social and economic sustainability performance of master planning projects, infrastructure and buildings (Building Research Establishment Ltd 2021, 2020). The BREEAM sustainability standards are evaluated under nine categories: Energy, Waste, Water, Materials, Health and Wellbeing, Transport, Pollution, Land Use \& Ecology, and Management (BRE group, 2019). CEEQUAL sustainability rating scheme for infrastructure by the BRE includes public realm assessment. Physical safety and comfort are not included in the criteria of assessment, or in the standards; though health and well-being is assessed through the above mentioned nine categories, none address the problems on physical safety and comfort (BRE Group, 2019).

\subsection{LEADERSHIP IN ENERGY AND ENVIRONMENTAL DESIGN (LEED) FOR CITIES AND COMMUNITIES}


LEED is an American sustainability rating system, which commenced as a green building rating system (Green Building Council, 2019). LEED for Cities and Communities assists the planners to design and evaluate natural systems, energy and transportation elements etc. of the cities aligned with the UN Sustainable Development Goals (U.S. Green Building Council, 2019). The LEED sustainability progress tracking objectives as per the U.S. Green Building Council (2019) does not emphasize the requirement of physical safety and comfort.

\subsection{INTERNATIONAL ROAD ASSESSMENT PROGRAMME (IRAP)}

The tools developed by the International Road Assessment Programme (iRAP) are based on achieving the SDG goal 3 and 4(International Road Assessment Programme [iRAP], 2021). Accordingly they are designed for street risk mapping, star rating, and policy and performance tracking to prevent injuries and deaths (iRAP, 2021). As per the iRAP (2021), the star rating tool provides a measure of the safety of roads for different user categories. The target through the process is to improve the road qualities in order to achieve more stars that depict the improved safety levels of streets. The road safety toolkit by iRAP (2021) is used to identify the causes and prevention of road crashes. However it is not established as a 'sustainability status' measurement tool, but a tool to achieve SDG 3 and 4. Therefore this tool is not prioritized among the developing countries such as Sri Lanka.

\subsection{CONCLUSION - SUSTAINABILITY ASSESSMENT TOOLS REVIEW}

In conclusion, it can be stated that all the sustainability measurement tools around the globe are based on the UN Sustainable Development Goals, which does not underscore the significance of physical safety and comfort, and are focused typically on the 'Green concept' of buildings, rather than open public realm. Street assessment tools such as 'International Road Assessment Programme: Road Safety Toolkit' contribute in identifying causes of street safety threats and rectifying accordingly (International Road Assessment Programme, 2021). Global Designing Cities Initiative (2016) street Design Guidelines are available to ensure street safety and comfort for different street elements. However such design assessment and guideline tools are not efficiently utilised or executed as they do not provide a global rating for ubiquitous concept such as 'sustainability', though they contribute in achieving the Sustainable Development Goals (Global Designing Cities Initiative, 2016). Thus it is vital to incorporate physical safety and comfort factors of streets as a criteria of tools that are universally identified as public realm sustainability rating tools.

\subsection{OVERVIEW ON THE CONCEPT OF SUSTAINABILITY IN SRI LANKA WITH REGARD TO PHYSICAL SAFETY AND COMFORT OF USERS OF STREETS}

The Sustainability Development Goals in Sri Lanka are entirely based upon the UN Sustainability Development goals (United Nations Statistics Division, 2018, Department of Census and Statistics, 2018). Accordingly, Department of Census and Statistics (2018) states that the indicator of SDG 3.6 of the UN is the 'death rate due to traffic injuries' (figure 5), and that of the SDG 11.2 is the 'Proportion of population that has convenient access to public transport, by sex, age and persons with disabilities'. Both the indicators are primarily determined by the physical safety and comfort level, which accentuates the need for inclusion of physical safety and comfort as an element of sustainability rating. As summarized in the literature analysis, the goal 3.6 is not achieved by Sri Lanka, and instead it is in a very critical state considering the increase in the number of road accident deaths (Department of Census and Statistics, 2018).

The SDG 11.2 is directed primarily towards implementing modern and efficient public transport systems rather than ensuring physical safety and comfort, as could be understood from the report by United Nations, (2018). It is considered a tier 2 indicator for which the criteria is defined clearly, but the partner countries do not assess and produce regular reports. Sri Lanka does not even hold a comprehensive tool to estimate the sustainability of transport system (Bandara, s, 2017). The Department of Census and Statistics (2018) has not published any data on this indicator of the UN SDG goal 11.2 and neither has the UN SDG tracker (Out World In Data, 2021). Globally only 50\% of the population has convenient access to public transport (Majeed, 2021). In Sri Lanka, since 2000 the private vehicular mode had tripled due to lack of convenience of public transport, though $57 \%$ of total passengers depend on public transport (Majeed, 2021). Therefore it essential to take effective actions to augment the quality of public transport conforming to required minimum physical safety and comfort levels to achieve sustainability.

In addition, 'Vision 2025: Sri Lanka's Path to Prosperity' launched by the government of Sri Lanka is planning to elevate the country's standard of living including concerns on infrastructure and road developments (World Bank Group, 2017). But the target of the plans are based upon the economic 
augmentation rather than any other factors. Therefore, as in any other global sustainability assessment tool discussed above, the physical safety and comfort is disregarded, resulting in a high annual road crash deaths per capita, which is almost double that of any other high-income country (The World bank, 2020).

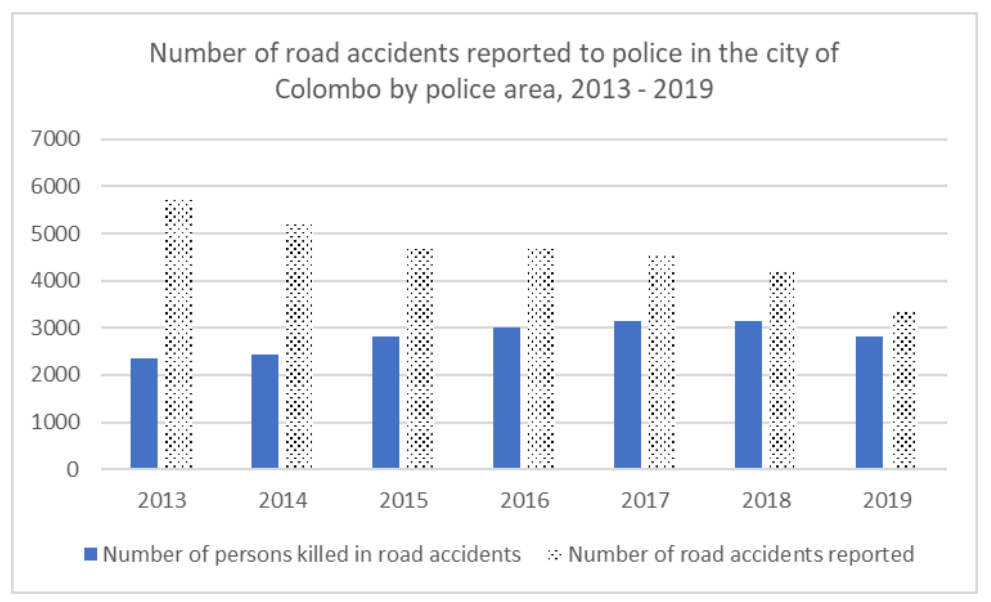

Figure 5, Number of road accidents reported to police in the city of Colombo by police area, 2013 - 2019 (Author's representation of the data from Department of Census and Statistics, 2018)

\section{Conclusion}

Road accidents are a major global problem that require immediate and effective solution. Through years of development all the actions taken to solve the problem on road accidents are focussed on rectifying and amending the laws and regulations on vehicular speed, road signage, charging fines from traffic offenders etc. to control user behaviour, which is not efficient as could be observed with the increasing rate of traffic fatalities. Regardless the action of users, roads have to be designed to prevent any crashes, because controlling the diverse user behaviour is beyond the capacity of authorities. Accordingly, designing streets ensuring physical safety and comfort becomes vital. Considering sustainability as being one of the prioritized and best implemented global concept, it is suggested that implementing physical safety and comfort as a key components of sustainability would be much effective. The 'pillars' of sustainability, which are Environmental , Economic, Social and Institutional factors, do not highlight physical safety and comfort of users. Most of the globally practiced sustainability measurement tools also focus primarily on 'green' concept of buildings rather than ensuring user physical safety and comfort in public realm as could be observed from the table 3.

\begin{tabular}{|c|c|c|c|}
\hline \multirow[t]{2}{*}{ Problem } & \multicolumn{2}{|c|}{ Action / Assessment tool } & \multirow[t]{2}{*}{ Target } \\
\hline & Plan / Indicator & Outcome / results & \\
\hline \multirow{7}{*}{$\begin{array}{l}\text { Higher number } \\
\text { of road } \\
\text { accident } \\
\text { injuries and } \\
\text { increasing road } \\
\text { accident } \\
\text { deaths }\end{array}$} & \multicolumn{3}{|c|}{ United Nations Sustainable Development Goal } \\
\hline & $\begin{array}{l}\text { death rate due to traffic injuries } \\
\text { in Colombo }\end{array}$ & $\begin{array}{l}\text { Has reduced only by } \\
10 \% \text { from } 2018- \\
2019 . \text { Not achieved. }\end{array}$ & $\begin{array}{l}\text { 3.6: 'death rate due to traffic } \\
\text { injuries', and that of the target }\end{array}$ \\
\hline & $\begin{array}{l}\text { Proportion of population that } \\
\text { has convenient access to public } \\
\text { transport, by sex, age and } \\
\text { persons with disabilities in } \\
\text { Colombo }\end{array}$ & $\begin{array}{l}\text { Not yet recorded or } \\
\text { assessed either locally } \\
\text { or globally. Therefore } \\
\text { result is not known. }\end{array}$ & $\begin{array}{l}\text { 11.2: 'Proportion of population } \\
\text { that has convenient access to } \\
\text { public transport, by sex, age and } \\
\text { persons with disabilities' }\end{array}$ \\
\hline & \multicolumn{3}{|l|}{ Sustainability Assessment tools } \\
\hline & $\begin{array}{l}\text { Comprehensive Assessment } \\
\text { System for Built Environment } \\
\text { Efficiency (CASBEE) }\end{array}$ & & $\begin{array}{l}\text { "CASBEE-City" tool to evaluate } \\
\text { the environmental performance } \\
\text { of cities }\end{array}$ \\
\hline & Green Building Index (GBI) & & $\begin{array}{l}\text { Environmental rating system to } \\
\text { address the environmental, social } \\
\text { and economic issues }\end{array}$ \\
\hline & $\begin{array}{l}\text { Sustainability assessment tools } \\
\text { by BRE: } \\
\text { Building Research } \\
\text { Establishment Environmental } \\
\text { Assessment Method (BREEAM) } \\
\text { and }\end{array}$ & & $\begin{array}{l}\text { Assess the environmental, social } \\
\text { and economic sustainability } \\
\text { performance of master planning } \\
\text { projects, infrastructure and } \\
\text { buildings. CEEQUAL sustainability } \\
\text { rating scheme for infrastructure }\end{array}$ \\
\hline
\end{tabular}




\begin{tabular}{|l|l|l|}
\hline & $\begin{array}{l}\text { CEEQUAL sustainability rating } \\
\text { scheme for infrastructure }\end{array}$ & $\begin{array}{l}\text { by the BRE includes public realm } \\
\text { assessment }\end{array}$ \\
\cline { 2 - 4 } & $\begin{array}{l}\text { Leadership in Energy and } \\
\text { Environmental Design (LEED) } \\
\text { for Cities and Communities }\end{array}$ & $\begin{array}{l}\text { LEED for Cities and Communities } \\
\text { assists the planners to design and } \\
\text { evaluate natural systems, energy } \\
\text { and transportation elements etc. } \\
\text { of the cities }\end{array}$ \\
\cline { 2 - 4 } & & $\begin{array}{l}\text { Improve the level of road safety in } \\
\text { order to achieve SDG 3 and 4, } \\
\text { through assessment of road } \\
\text { design using different tools to } \\
\text { identify the cause of risk and } \\
\text { suggest improvements } \\
\text { accordingly }\end{array}$ \\
\hline & $\begin{array}{l}\text { International Road Assessment } \\
\text { Programme (iRAP) }\end{array}$ & \multicolumn{2}{|l}{} \\
\hline
\end{tabular}

Table 3, Sustainability definition and assessment tool conclusion table, (Author, 2020).

Considering the international sustainability concepts and assessment tools, it is evident that none of the tools that endorse 'sustainability status' have integrated the physical safety and comfort as an element. Therefore, the analysis concludes that in order to reduce street accidents, physical safety and comfort should be included as a criteria in the formulation of any sustainability assessment tool, which is wellestablished and prioritized internationally by all designers and governing authorities, to obtain global identity.

\section{Acknowledgements}

This work is supported by the Accelerating Higher Education Expansion and Development (AHEAD)- DOR Grant affiliation with Ministry of Higher Education \& University Grants Commission and funded by the World Bank.

\section{References}

Ahmed-Kristensen, S., \& Stavrakos, S-K. (2012). Definition of comfort in design and key aspects- A literature review. In Proceedings of NordDesign Conference 2012 Aalborg University, Center for Industrial Production.

Bandara, s. (2017). 'Sustainable Transport Initiatives in Sri Lanka'. Capacity Building Workshop on Sustainable, Urban Transport Index [online]. Available at :

https://www.unescap.org/sites/default/files/11.\%20Sus\%20Transport\%20Initaitives\%20in\%20Sri\%20LankaProf.Saman_.pdf (Accessed: 17 June 2021)

BRE group. (2019). Standards [online]. Available at: https://www.bregroup.com/services/standards/ (Accessed: 18 June 2021)

BRE Group. (2019). Version 5 - CEEQUAL, CEEQUAL - The Evidence-Based Sustainability Assessment, Rating and Awards Scheme for Civil Engineering, Infrastructure, Landscaping and Public Realm Projects [online]. Available at : https://www.ceequal.com/version-5/ (Accessed: 18 June 2021)

Building Research Establishment Ltd 2021. (2020). BREEAM [online]. Available at :

https://www.breeam.com/discover/why-choose-breeam/ (Accessed: 18 June 2021)

Burford G, Hoover E, Velasco I, Janoušková S, Jimenez A, Piggot G, Podger D, Harder MK. (2013). 'Bringing the “Missing Pillar" into Sustainable Development Goals: Towards Intersubjective Values-Based Indicators' Sustainability. 2013; 5(7):3035-3059 [online]. Available at: https://doi.org/10.3390/su5073035 (Accessed: 17 June 2021)

Criterion Planners - a Global Survey of Urban Sustainability Rating Tools (2014) [online]. Available at: http://crit.com/wp-content/uploads/2014/11/criterion_planners_sustainability_ratings_tool.pdf (Accessed: 17 June 2021)

Department of Census and Statistics. (2019). 'Number of road accidents, 2013 - 2019' [online]. Available at: http://www.statistics.gov.lk/abstract2020/CHAP7 (Accessed: 17 June 2021)

Department of Census and Statistics. (2018). 'Sri Lanka, Sustainable Development Goals'. Department of Census and Statistics, Sri Lanka [online]. Available at: http://www.statistics.gov.lk/sdg/index.php/sdg/page/SDG_Goals (Accessed: 17 June 2021)

Global Design Cities Initiative. (2016). 'Global Street Design Guide', ISBN: 978-1-61091-494-9, [online]. Available at: https://globaldesigningcities.org/wp-content/uploads/guides/global-street-design-guide.pdf (Accessed: 18 October 2021)

Green Building Council. (2019). 'About: Brand | U.S. Green Building Council. LEED' [online]. Available at: https://www.usgbc.org/about/brand (Accessed: 17 June 2021) 
Green Building Index Sdn Bhd. (2017). 'GBI Assessment Criteria for Township Version 2.0 Pilot' [online]. Available at: https://www.greenbuildingindex.org/Files/Resources/GBI\%20Tools/GBI\%20Township\%20Tool\%20V2.0.pdf (Accessed: 17 June 2021)

Harsimran Kaur, Pushplata Garg (2019), 'Urban sustainability assessment tools: A review, Journal of Cleaner Production', Volume 210, 2019, Pages 146-158, ISSN 0959-6526, [online]. Available at:

https://doi.org/10.1016/j.jclepro.2018.11.009. (Accessed: 17 June 2021)

International Road Assessment Programme (2021). 'Road Safety Toolkit' [online]. Available at:

http://toolkit.irap.org/ (Accessed: 16 October 2021)

Japan Sustainable Building Association. (2014). CASBEE-City. '6.1Comprehensive Assessment System for Built Environment Efficiency' [online]. Available at: https://www.ibec.or.jp/CASBEE/cas_city/casbee_city2013.htm (Accessed: 17 June 2021)

Kristianssen, A.-C., Andersson, R., Belin, M.-Å., \& Nilsen, P. (2018). Swedish Vision Zero policies for safety - A comparative policy content analysis. Safety Science, 103, 260-269. Available at: https://www.sciencedirect.com/science/article/pii/S0925753517309013 (Accessed: 17 June 2021)

MAJEED, S. A. J. A. A. A. (2021). 'Sustainable Development Goal (SDG 11): Sustainable Cities and Communities Engineers must act fast to get it right'. The Institution of Engineers Sri Lanka [online]. Available at: https://iesl.lk/SLEN/54/SDG.php (Accessed: 17 June 2021)

National Association of City Transportation Officials. (2017). USA. Urban Street Design Guide [online]. Available at: https://nacto.org/publication/urban-street-design-guide/ (Accessed: 16 October 2021)

National Institute of Building Sciences. (2021). 'Provide Comfortable Environments / WBDG - Whole Building Design Guide', National Institute of Building Sciences [online]. Available at: https://www.wbdg.org/design-

objectives/productive/provide-comfortable-environments (Accessed: 17 June 2021)

Novosad, P., Werker, E. (2019). 'Who runs the international system? Nationality and leadership in the United Nations Secretariat. Rev Int Organ' [online]14, 1-33. Available at: https://doi.org/10.1007/s11558-017-9294-z (Accessed 10 October 2021)

Out World In Data. (2021). 'Goal 11: Sustainable Cities and Communities - SDG Tracker'. Our World in Data [online]. Available at: https://sdg-tracker.org/cities (Accessed: 17 June 2021)

Perera, Clifford. (2016). 'Legal aspects of motor traffic trauma in Sri Lanka, Egyptian Journal of Forensic Sciences', Volume 6, Issue 4, 2016, Pages 342-346, ISSN 2090-536X, [online]. https://doi.org/10.1016/j.ejfs.2016.02.001. Available at: https://www.sciencedirect.com/science/article/pii/S2090536X16000174 (Accessed: 17 June 2021)

Serenella Sala, Biagio Ciuffo, Peter Nijkamp, (2015). 'A systemic framework for sustainability assessment', Ecological Economics, Volume 119, Pages 314-325, ISSN 0921-8009, [online].

https://doi.org/10.1016/j.ecolecon.2015.09.015.

https://www.sciencedirect.com/science/article/pii/S0921800915003821 (Accessed: 17 June 2021)

Serkan Yıldız, Serkan Kıvrak, Arzuhan Burcu Gültekin, Gökhan Arslan. (2020). 'Built environment design - social sustainability relation in urban renewal', Sustainable Cities and Society, Volume 60, (2020), 102173, ISSN 22106707,[online]. https://doi.org/10.1016/j.scs.2020.102173. Available at: https://www.sciencedirect.com/science/article/pii/S2210670720301608 (Accessed: 17 June 2021)

S. Sun, Q. Zhou, S. Lal, H. Xu, K. Goh \& Y. D. Wong. (2020). 'Quantifying performance of sheltered link-way facility in Singapore using human-centric indicators', International Journal of Urban Sustainable Development, DOI: 10.1080/19463138.2020.1858422.

The World Bank, (2020). 'Delivering Road Safety in Sri Lanka'. Leadership Priorities and Initiatives to 2030, [online]. Available at: https://openknowledge.worldbank.org/bitstream/handle/10986/33341/ROAD\%20SAFETY\%20IN\%20SRI\%20LAN KA.pdf?sequence=1\&isAllowed=y (Accessed: 17 June 2021)

The World Bank, (2020b). Urban Development Overview. World Bank [online]. Available at:

https://www.worldbank.org/en/topic/urbandevelopment/overview (Accessed: 16 October 2021)

United Nations Development Programme. (2015). 'Sustainable Development Goals / United Nations Development Programme' [online]. Available at: https://www.undp.org/sustainable-developmentgoals?utm_source=EN\&utm_medium=GSR\&utm_content=US_UNDP_PaidSearch_Brand_English\&utm_campaign=CEN TRAL\&c_src=CENTRAL\&c_src2=GSR\&gclid=CjwKCAjwoNuGBhA8EiwAFxomA-

L4UR8FYq5NKh2jQxtB3GEdsxgsBa07cQrt_CzdNrOnEJMvnJWlgBoCpZYQAvD_BwE (Accessed: 17 June 2021)

United Nations Economic Commission for Europe. (2015) 'Together with UNECE on the road to safety: cutting road traffic deaths and injuries in half by 2020'. Geneva. [online]. Available at : https://euagenda.eu/upload/publications/untitled-62401-ea.pdf

United Nations Statistics Division. (2018). 'Global indicator framework for the Sustainable Development Goals and targets of the 2030 Agenda for Sustainable Development'. United Nations Statistics Division, [online]. Available at: https://unstats.un.org/sdgs/indicators/Global\%20Indicator\%20Framework\%20after\%20refinement_Eng.pdf (Accessed: 17 June 2021) 
United Nations. (1987). 'Sustainability' [online]. Available at: https://www.un.org/en/academicimpact/sustainability (Accessed: 17 June 2021)

United Nations. (n.d.). 'Sustainable transport', Sustainable Development Knowledge Platform [online]. Available at: https://sustainabledevelopment.un.org/topics/sustainabletransport (Accessed: 17 June 2021)

United Nations. (2018). 'Voluntary National Review 2018: Sri Lanka : Sustainable Development Knowledge Platform'. Sustainable Development Goals, Knowledge Platform [online]. Available at: https://sustainabledevelopment.un.org/memberstates/srilanka (Accessed: 17 June 2021)

United Nations. (2002). 'World Summit on Sustainable Development'. United Nations Sustainable Development Goals Knowledge Platform [online]. Available at: https://www.un.org/ga/search/view_doc.asp?symbol=A/C.2/57/L.83\&Lang=E (Accessed: 17 June 2021)

U.S. Green Building Council. (2019). 'LEED for Cities and Communities' | U.S. Green Building Council [online]. Available at : https://www.usgbc.org/leed/rating-systems/leed-for-cities (Accessed: 17 June 2021)

William W. Harper. (1952-1953). 'Prevention and Reduction of Injuries in Traffic Collisions', 43 J. Crim. L. Criminology \& Police Sci. 515 [online]. Available at: https://scholarlycommons.law.northwestern.edu/cgi/viewcontent.cgi?article=4056\&context=jclc (Accessed: 16 October 2021)

World Bank Group. (2017). 'Vision 2025: Sri Lanka's Path to Prosperity', World Bank [online]. Available at : https://www.worldbank.org/en/news/feature/2017/10/17/vision-2025-sri-lankas-path-to-prosperity (Accessed: 17 June 2021)

World Health Organization. (2020). 'Road traffic injuries - Fact Sheet' [online]. Available at: https://www.who.int/news-room/fact-sheets/detail/road-traffic-injuries (Accessed: 17 June 2021)

World Health Organization. (2017). 'Save lives: a road safety technical package'. World Health Organization, License: CC BY-NC-SA 3.0 IGO , [online]. Available at: https://apps.who.int/iris/handle/10665/255199 . (Accessed: 17 June 2021)

World Health Organization. (2018). 'Global Status Report 2018'. World Health Organization. ISBN 978-92-4156568-4 [online]. Available at: https://www.who.int/publications/i/item/9789241565684 (Accessed: 17 June 2021)

Yigitcanlar, T., \& Dur, F. (2010). Developing a Sustainability Assessment Model: The Sustainable Infrastructure, Land-Use, Environment and Transport Model. Sustainability, 2(1), 321-340. doi:10.3390/su2010321 